\title{
Paul's Death and Resurrection in Acts 27-28? A Literary Comparison with the Gospel of Luke
}

\author{
VADIM WITTKOWSKY \\ Humboldt University Berlin \\ email: wittkovx@hu-berlin.de \\ ORCID: 0000-0002-8051-1219
}

\begin{abstract}
It was claimed more than once that the journey of Paul and his landing on the shore of Malta in the last two chapters of the Book of Acts can be interpreted as a theological parallel to the account of death and resurrection of Jesus. There are, to be sure, some reasonable arguments in favor of that, such as close relationship between death and death risk or similarities to the journey of Jonah. But can it be convincingly argued that Luke really did intend a parallelism of this kind in Acts 27-28? The paper deals with literary elements of Luke 23-24 to make this hypothesis more conclusive.
\end{abstract}

KeYwords: Luke 23-24 - Acts 27-28 - Book of Jonah - Biblical Rewriting - Literary Comparison

I Rewritten Bible" and "literary creativity" became popular topics of the bibRlical scholarship in the last decennia, not only regarding the Jewish but also the Christian literature, especially the New Testament. One of the most interesting early Christian writers is in this sense the author of the Gospel of Luke and Book of Acts. This article deals with his method of parallelizing texts of his two works and using at the same time different texts, which were either a part of the Bible in his own times ("Old Testament") or should become a part of it later ("New Testament"). ${ }^{1}$

It is clearly one of the most difficult problems of the composition of LukeActs, in what relationship stands the last journey of Paul (Acts 27-28) to the last chapters of the Lukan Gospel, although it is quite clear, as Richard Pervo puts it, that "in the comparable structural slot where the Gospel tells of the execution of Jesus and his subsequent vindication through resurrection, Acts tells the story of the voyage". Pervo is correct when he continues that: "an absence of parallelism in Acts 27 would threaten the entire hypothesis of symmetry [...] Investigation of the possibility that Acts 27 evokes $23-24$ is warranted by its length and by its

1 Especially important for our topic is a conference volume contribution of M. Müller, ,Acts as Biblical Rewriting of the Gospels and Paul's Letters", Luke's Literary Creativity (ed. J.T. Nielsen - M. Müller) (LNTS 550; London - New York: Bloomsbury - T\&T Clark 2016) 96-117. See also H. Omerzu, Der Prozeß des Paulus: Eine exegetische und rechtshistorische Untersuchung der Apostelgeschichte (BZNW 115; Berlin - New York: De Gruyter 2002). 
location in the narrative". ${ }^{2}$ Walter Radl, a German New Testament scholar, one of the authors quoted here by Pervo, ${ }^{3}$ published (1975) a dissertation in which he deals with the parallels between the Lukan figures of Jesus and Paul. ${ }^{4}$ In the chapter I.8 the last sections of both Luke and Acts are Radl's subject matter. ${ }^{5}$ Unfortunately, precisely in this chapter Radl does not use his normal method of comparative analysis of Lukan texts, although his remarks there are quite interesting as well.

We will now undertake such a closer examination, because only on this base a conclusion can be reached on what motives and details of the last two chapters of Acts really do have correlations in the Gospel of Luke (or, possibly, in the pretexts of Luke). Our first comparison is based on the sound idea that the journey of Paul can be taken as a rewritten journey of the Old Testament prophet Jonah. ${ }^{6}$

\section{Three Days in the Tomb and the Journey of Jonah}

\subsection{A Corrected Prophecy of Jesus: Luke 11:29-32 vs. Matt 12:40-42}


as the Markan original version puts it (Mark 8:31; 9:31 and 10:34). Matthew and Luke (Matt 16:21; 17:23; 20:19; Luke 9:22; 18:337) replace that by $\tau$ ñ $\tau$ ๆítn $\dot{\eta} \mu \varepsilon \dot{\rho} \rho \mathbf{c}$ which has probably to do with the problem of "the sign of Jonah": the phrase $\mu \varepsilon \tau \grave{\alpha} \tau \rho \varepsilon i \bar{\zeta} \dot{\eta} \mu \varepsilon \dot{\rho} \rho \varsigma_{\varsigma}$ could be understood in the sense "on the third day"

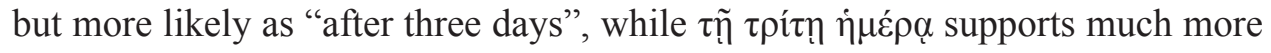
unambiguously the first option. ${ }^{8}$

Possibly there was a story in circulation about how Jesus claimed a connection of his death and the following resurrection with an Old Testament "prophecy" or

2 R. Pervo, Acts: A Commentary (Hermeneia; Minneapolis, MN: Fortress 2009) 649. Cf. also further below (653): "It is difficult to deny that, at some level, Acts is speaking of the same issues expounded in Luke 23-24".

3 He names also Rackham, Goulder, Kratz, Jacobson, Aletti, and Tannehill (Pervo, Acts, 649, no 46). However, not all of them seem to share the opinion that the connections between Acts 27(-28) are more important than e.g. the parallel between Acts 27:33-38 and Luke 22:19.

4 W. Radl, Paulus und Jesus im lukanischen Doppelwerk: Untersuchungen zu Parallelmotiven im Lukasevangelium und in der Apostelgeschichte (Europäische Hochschulschriften 23/49; Bern: Herbert Lang - Frankfurt am Main: Peter Lang 1975).

5 Radl, Paulus und Jesus, 222-251. Its title is "Is the way of Paul to Rome a parallel to Jesus' death and resurrection" (Ist der Weg des Paulus nach Rom eine Parallele zu Jesu Tod und Auferstehung?).

6 Radl, Paulus und Jesus, 229-230.

7 The same also in Luke 24:7. Luke 9:44 does not contain these words.

$8 \quad$ See M.D. Goulder, Luke: A New Paradigm (JSNTSup 20; Sheffield: Academic Press 1989) II, 439. 
a prototypical account, and this story was used by Matthew in his Gospel. ${ }^{9}$ So the saying about the "sign of Jonah" found its way to Matt 12:40-42.

Matt 12:40 reads as follows: "For as Jonah was in the belly of the whale three days and three nights, so shall the Son of Man be in the heart of the earth three


version of the Matthean text: "For as Jonah was as sign to the Ninevites, so shall the Son of Man be also to this generation" (Luke 11:30). ${ }^{10}$ Matthew is also talking about Nineveh (12:41) but Luke retained that (11:32), so he has a deliberate repetition in his pericope. ${ }^{11}$ In effect, the words about Jonah as a sign for the Ninevites (with a clear allusion to Jonah 3:4 in the LXX version ${ }^{12}$ ) are a Lukan substitution for the Matthean quotation from Jonah 2:1 in Matt 12:40. Matthew is interested in the Ninevites only as a counterpart of the "Queen of the South" (Matt 12:42 par Luke 11:31) but Luke has them twice. At the same time Luke omits the Matthean words about "three days in the belly". Possibly he is just relocating this topic? ${ }^{13}$ The text which can make this constellation clearer is chapter 27 of the Book of Acts.

\subsection{A Sea Voyage to the Western Mediterranean: Acts 27 and Jonah 1}

Paul starts his sea voyage in Acts 27:1, which should bring him far into the West. This alone already seems to recall the one of the few - if not the only - journey of this kind, which has been told in the Bible so far. This is the famous flight of the just mentioned prophet Jonah from the Israelite Northern Kingdom to Tartessus (Tarshish), the most remote place on the opposite shore of Mediterranean sea (Jon 1). This journey was anything but smooth, because first of all a strong storm began forcing the ship crew to look for rescue ways. With that the Lukan account ties in.

9 Matthew was possibly even the inventor of this saying (cf. Matt 16:4). The "Two-Document theory" assumes a "logion" from the "lost source Q" (see footnote below).

10 The supporters of the "Two-Document theory" tend to see in Matt 12:40 a Matthean revision of "Q", which is supposedly Lukan in this case (then also the repetition stood in Q and was avoided by Matthew). "There is agreement that the resurrection link with Jonah stems from Matthew" (Goulder, Luke, 514).

11 "What he (Luke) has done subtly is to drop the resurrection reference, and to make the comparison between Jonah and Jesus as straightforward preachers of repentance. So the saying becomes relevant to its context, and also to its introduction; for blessed are those who hear the word of greater than Jonah and keep it" (Goulder, Luke, 512).

12 "Yet three days, and Nineveh shall be overthrown!", while MT has "fourty days".

13 Cf. Th.L. Brodie, The Birthing of the New Testament: The Intertextual Development of the New Testament Writings (Sheffield: Phoenix 2004) 262: “Generally, in Luke's relationship to Matthew - as in Luke's relationship to Mark - some apparent omissions do not exclude dependence. Very often the material is not omitted; it is transformed or/and relocated. The challenge is to find it." 
The description of an emergency situation starts with 27:14, which section (until 27:26) contains many allusions to Jonah 1. In Jonah 1:4 and Acts 27:14 the storm begins, and the people on board have a scare (Jonah 1:5 - Acts 27:17). They make an attempt to save the ship by jettisoning cargo from it (Jonah 1:5 Act 27:18f). ${ }^{14}$

Paul is - like Jonah - the passenger, on whom the course of the journey is decisively dependent (Jonah 1:12 - Acts 27:24). Each of them is a servant of a god who is the Only Mighty for both authors (Jonah 1:9-Acts 27:23), and each of them is convinced that the storm can be calmed down by this god, so that all people on board still can be saved (Jonah 1:12 - Acts 27:22,25f). ${ }^{15}$

This series of analogies shows already very clear that the sea trip of Paul is to be read before the background of the chapter 1 of the Old Testament Book of Jonah. But in the text of Acts there is also an allusion on "three days and three nights" from Jonah 2:1. Such an allusion can be seen in the references of an equal number of days and nights spent on the sea during the storm: in Act 27:27 the "fourteenth night" ${ }^{16}$ is mentioned, in 27:33 Paul is talking about the "fourteenth day". ${ }^{17}$

The Matthean "three days and three nights" are transferred by Luke from the Gospel into the Book of Acts, and this is precisely the place - between danger and salvation - which is compositionally correlated with the "rest of death" of Jesus (Luke 23:54-56).

\section{The Hope Comes Back: Luke 24 vs. Acts 27}

The message about the resurrection (Luke 24:4-7) is delivered by angels (or, more precisely, by "men in shining garments") and is a real revelation only for women who heard it (24:8-10), while it remained at best an amazing but very dubious report for others $(24: 11 \mathrm{f}, 22-24)$. Also the news of the salvation of the

14 "The language of vv. 18-19 is somewhat repetitious [...] lending force to the view that the narrator

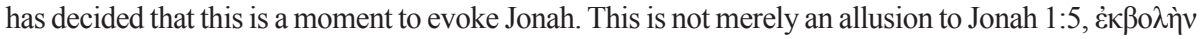

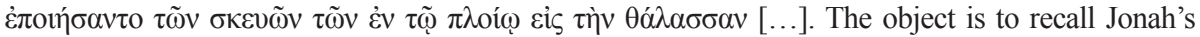
,death and resurrection"” (Pervo, Acts, 659). Cf. C.R. Holladay, Acts: A Commentary (Louisville: Westminster John Knox 2016) 491, no 28: "See Jonah 1:5 (with phraseology strikingly similar to

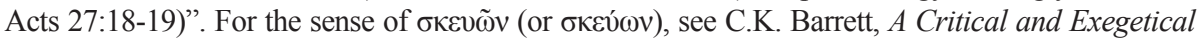
Commentary on The Acts of the Apostles (Edinburgh: Clark 1998) II, 1198.

15 See Radl, Paulus und Jesus, 227-228.

16 'Paul's mention of the ,fourteenth day' (v. 33) repeats the narrative report of verse 27, thereby linking the two sections (27:27-32 and 27:33-38)" (Holladay, Acts: A Commentary, 496). See now also D. Christopher, The Appropriation of Passover in Luke-Acts (WUNT 2.476; Tübingen: Mohr Siebeck 2018) 188-191.

17 Possibly an allusion to 14th day of Nisan. Cf. Pervo, Acts, 663 ("The fourteenth was also the night of the Passover (Exod 12:6). This can be taken as an exodus symbol"). 
passengers from the mortal danger is first given to Paul alone. It is noteworthy that he, too, is not informed about this by Jesus himself (cf. Acts 18:9f; 23:11) but by an angel. Only then do others learn about it, which initially, however, does not encourage them, for example, to eat something (Acts 27:21-26)..$^{18}$ The actual acknowledgment of the good news fails to appear, therefore, both in Luke 24 and in Acts 27, a little longer than if the real faith had been there. The hope wanes, as

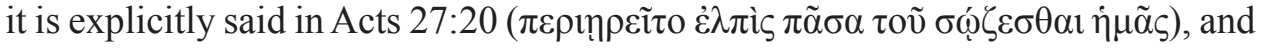
the same happened to the followers of Jesus still on the third day after his crucifixion: "But we were hoping ( $\dot{\eta} \lambda \pi i \zeta o \mu \varepsilon v$ ) that it was he who was going to redeem Israel. Indeed, besides all this, today is the third day since these things happened" (Luke 24:21). Also, the "we" - quasi the new Israel gathered on the ship - lose the last hope, although it is exactly the time to hope for the best and to be in good spirits. They aren't ready to follow Paul's call $\varepsilon \dot{\theta} \theta v \mu \varepsilon i \tau \varepsilon$ (Acts 27:22,25). But the turn will come soon.

In the Emmaus scene (Luke 24:28-32) the Risen shows himself to his two disciples. At first, they do not recognize him (because their eyes were "held" 24:16), but only very shortly before his disappearance do they understand that they were talking not to an unknown person but to Jesus himself. They can identify him correctly only when he is breaking bread before them (24:30f).

The corresponding pericope in Acts (27:33-38) runs parallel to it: Paul breaks bread before other passengers and invokes them to participate in the meal (27:35,

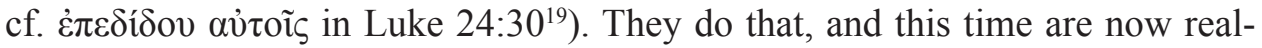
ly "in good spirits" ( $\varepsilon v 00 \mu \mathrm{or}$ - Acts 27:36, cf. the encouragements in 27:22;25 which were initially unsuccessful). The hope is now back - like in Luke 24:31 (cf. 24:35) after the breaking of the bread (was it not in Jesus' name?). After such a-divine - meal (Acts 27:36) the simple bread ( $\sigma \tilde{i} \tau \circ \varsigma$ ) is no longer necessary and can be thrown overboard $(27: 38){ }^{20}$

\section{The Death is Defeated Thrice: Acts 27:42-28:6 vs. Luke 23:35b-39}

Like in the Book of Jonah (1:15f) the storm is over also in Acts 27:39-44. All are alive as the Old Testament prophet (Jon 1:12) and Paul (Acts 27:22) have

\footnotetext{
18 Already when Paul turns to the people with these words (Acts 27:21 and not only later, cf. 27:33), they were hungry for a long time.

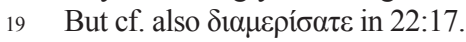

20 About the use of Mark 8:1-26 ("great omission” material) in Acts 27 see V. Wittkowsky, „Der Stoff der 'großen Auslassung' in Lukas 24 und Apostelgeschichte 27-28", Reading the Gospel of Mark in the Twenty-First Century (ed. G. Van Oyen) (BETL 301; Leuven: Peeters 2019) 847-866.
} 
promised still during the distress. But the danger for Paul is not over yet. The following (Acts 27:42-28:6) shows, how he succeeds to cope with upcoming challenges.

To be sure, the resurrection of Jesus in Gospel of Luke is not a process but a one-off event. However, looking back at the crucifixion scene one finds there the basis for the above-mentioned scenes of the Book of Acts.

The verses Luke 23:35-39 are of outstanding importance for the interpretation of the Lukan representation of the last journey of Paul (and vice versa):

35 And the people stood looking on. But even the rulers with them sneered, saying, 'He saved others; let Him save Himself if He is the Christ, the chosen of God'. 36 The soldiers also mocked Him, coming and offering Him sour wine, 37 and saying, 'If you are the King of the Jews, save yourself'. 38 And an inscription also was written over him in letters of Greek, Latin, and Hebrew: 'This is the king of the Jews'. 39 Then one of the criminals who were hanged blasphemed him, saying, 'If you are the Christ, save yourself and us.'

The spectators point out in their mockeries that Jesus cannot be a Messiah for three reasons. First, it is the crucifixion as such, i.e. an emergency situation which almost certainly leads to death of the crucified (23:35); second, the surveillance of the execution by the soldiers (23:36f) who are always ready to kill the condemned in a different way; ${ }^{21}$ third, Jesus is "numbered with the transgressors" (Luke 22:37) and is hanging now between two of them on his cross (23:32f,39), which seems to effectively prevent any identification of this messianic candidate with the real expected Messiah.

An interesting allusion to what will be performatively shown only in the last chapters of the Book of Acts can be noticed in the last words of Jesus before the execution: "For if they do these things in the green wood, what will be done in the dry?" (Luke 23:31). These words will turn out, as we will see soon, as a prophe$c y$, which is, however, not a direct reference to the events of the Jewish War but will be fulfilled in a certain way already inside the Lukan Doppelwerk, namely in the last chapters of the Book of Acts.

Also, besides of the storm at sea (emergency situation) Paul has to avoid an attempt of the soldiers to kill him on the ship (Acts 27:42f) ${ }^{22}$ and then, already on Malta, to survive a snake bite (28:3-5). These scenes in their combination have

21 Cf. also John 19:31-33.

22 "Vielleicht kam unter den Gefangenen ein Gerücht auf, dass die Soldaten ihn (i.e. Paul) töten wollten. Aber im lukanischen Bericht ist dieser Zug recht überraschend, weil ja zunächst - vor dem Eingreifen des Hauptmanns - für keinen der Schiffsinsassen eine Fluchtmöglichkeit sichtbar ist, am wenigsten für die wahrscheinlich mit einer Kette gefesselten Gefangenen" (E. Haenchen, Die Apostelgeschichte, 12th ed. [Göttingen: Vandenhoeck 1959] 633). 
very clear references to the scene on the cross making evident the connection between the ressurection of Jesus and the rescue of Paul from emergency in the Lukan "hypertext".

Already the verb $\delta 1 \alpha \sigma \omega \zeta \omega$ is used in the text of Acts four times between 27:43 and 28:4 (only six verses). ${ }^{23}$ And, as one can easily see, it is not about the only salvation but about several kinds of it. In 27:43 it is the Roman centurion Julius (the name was mentioned as early as 27:1), who prevents the killing of Paul by the soldiers. Furthermore, it is the rescue of the passengers from the water, already after the stilling of the storm $(27: 44 ; 28: 1)$. In $28: 4$ Luke is talking rather about the salvation from the emergency itself.

In 27:44 "boards" ( $\sigma \alpha v i \delta \varepsilon \varsigma)$ are mentioned which facilitate the rescue to land. Arrived there happy, Paul is dealing with a different kind of wood, namely with brushwood ( $\varphi \rho v ́ \gamma \alpha v \alpha)$ for a campfire ( $\pi \nu \rho \alpha ́)$. The first sort is naturally wet, whereas the second is $d r y$, so that a formal parallel to the Jesus' words in Luke

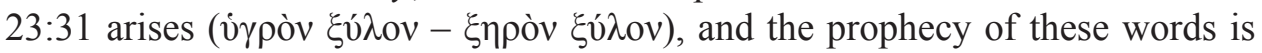
(first time) fulfilled in this way. ${ }^{24}$

The execution of Jesus by soldiers followed by a confession of a centurion about his innocence (Luke 23:36 - 23:47) has, as it already clear, its equivalence in Acts 27:42f, where the soldiers want to kill Paul, but a centurion prevents this. But a third danger remains, namely the danger of gaining bad reputation of a criminal (Luke 23:33,39f). Precisely that is still awaiting Paul after his double salvation.

He suffers a snakebite on the campfire (Acts 28:3), and the reaction of those present reminds very well of the crucifixion of Jesus together with two other


15:27 par Matt 27:38, who both avoid such a direct identification of Jesus as a criminal) and hence as a criminal. The "barbarians" (or "natives") say then in

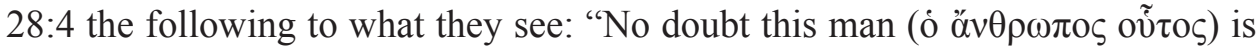
a murderer, whom, though he has escaped the sea, yet justice ( $\dot{\eta} \delta \dot{\kappa} \kappa \eta)$ does not allow to live". The wording should call in remembrance the reaction of the cen-

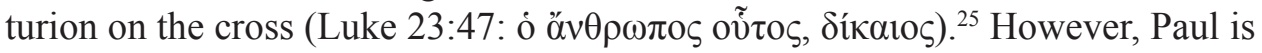
spared the death sufferings of Jesus again, because he "suffered no harm" ("̈ $\pi \alpha \theta \varepsilon v$

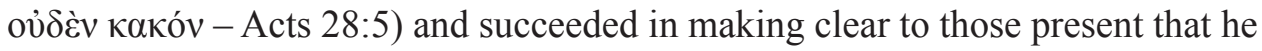
is (also) not a "murderer" (Acts 28:6). Luke draws attention to this analogy between the scenes on the cross and on the campfire through a further affinity: The "good thief" says about Jesus (Luke 23:41): "This man has done nothing wrong"

\footnotetext{
23 On the soteriological terms in Acts 27 see Christopher, Appropriation, 193-194.

24 Luke had an analogous antithesis $(\pi \tilde{\rho}-\beta a ́ \pi \tau \iota \sigma \mu \alpha)$ already in his Gospel (Luke 12:49f). Cf. J. Clabeaux, „The Story of the Maltese Viper and Luke's Apology for Paul”, CBQ 67 (2005) 609.

25 Clabeaux, „Story”, 607 with reference to póvos in in Luke 23:19.25 ("the crime of Barabbas”).
} 



is expressed very similarly: $\mu \eta \delta \varepsilon \dot{v}$ ót

The time of sufferings is clearly over. As Walter Radl correctly observes, the last chapter of the Book of Acts "makes of itself an impression of an 'Easter' chapter ... There is a cheerful, relaxed atmosphere in which the previous struggles and sufferings are, if not forgotten, so very far away - like in Luke 24 ". ${ }^{27}$

\section{Conclusion}

From the comparative analysis, it can be concluded that the narrative in the last chapters of the Book of Acts is not just an interlude of the novel type but a serious theological text that requires a closer look at what Luke wants to say about the resurrection of Jesus. What matters in his resurrection, is not that he remained alive - and indeed, the sense of Jesus' death lies in his ascension to heaven, in the return to his heavenly Father. Of real importance is that the resurrection is triumphing over various attempts to prevent the spread of the new doctrine, including its discrediting. The events that take place on Paul's way to Rome are a repetition of what happened to Jesus: Christianity again breaks its way, despite the obstacles like those that were on its way on the Easter days in Jerusalem.

\section{Bibliography}

Barrett, C.K., A Critical and Exegetical Commentary on The Acts of the Apostles (Edinburgh: Clark 1998) II.

Brodie, Th.L., The Birthing of the New Testament: The Intertextual Development of the New Testament Writings (Sheffield: Phoenix 2004).

Christopher, D., The Appropriation of Passover in Luke-Acts (WUNT 2.476; Tübingen: Mohr Siebeck 2018).

Clabeaux, J., „The Story of the Maltese Viper and Luke's Apology for Paul”, Catholic Biblical Quarterly 67 (2005) 604-610.

Goulder, M.D., Luke: A New Paradigm (JSNTSup 20; Sheffield: Academic Press 1989) II.

Haenchen, E., Die Apostelgeschichte, 12th ed. (Göttingen: Vandenhoeck 1959).

Holladay, C.R., Acts: A Commentary (Louisville: Westminster John Knox 2016).

26 These parallels are noticed by Pervo, Acts, 675 ("The scene evokes the passion and vindication of Jesus”). Cf. Clabeaux, ,Story”, 607. All three dangers can also be related to the situation of the Jewish War and it cannot be excluded that Luke meant that as well: the Christians (Jews and non-Jews) should not encounter a military emergency, siege of the city by Romans and the burning of Jerusalem (cf. Luke 21 par).

27 Radl, Paulus und Jesus, 237. 
Müller, M., „Acts as Biblical Rewriting of the Gospels and Paul's Letters”, Luke's Literary Creativity (ed. J.T. Nielsen - M. Müller) (LNTS 550; London - New York: Bloomsbury - T\&T Clark 2016) 96-117.

Omerzu, H., Der Prozeß des Paulus: Eine exegetische und rechtshistorische Untersuchung der Apostelgeschichte (BZNW 115; Berlin - New York: De Gruyter 2002).

Pervo, R.I., Acts: A Commentary (Hermeneia; Minneapolis, MN: Fortress 2009).

Radl, W., Paulus und Jesus im lukanischen Doppelwerk: Untersuchungen zu Parallelmotiven im Lukasevangelium und in der Apostelgeschichte (Europäische Hochschulschriften 23/49; Bern: Herbert Lang - Frankfurt am Main: Peter Lang 1975).

Wittkowsky, V., „Der Stoff der 'großen Auslassung' in Lukas 24 und Apostelgeschichte 27-28”, Reading the Gospel of Mark in the Twenty-First Century (ed. G. van Oyen) (BETL 301; Leuven: Peeters 2019) 847-866. 
